研究速報 免疫組織染色における胃癌患者の HLA-class-I 抗原の陽性率 北海道大学第 1 外科, 国立病院機構西札幌病院外科*

\begin{tabular}{|c|c|c|c|c|c|}
\hline 裕二 & 前田 & 好章 & 正村 & 裕紀 & 本間 \\
\hline 近藤 & 高橋 & 典彦 & 宇根 & 良衛* & 藤堂 \\
\hline
\end{tabular}

目的：特異的免疫療法である peptide-vaccine 療法 は, 効果を得るために腫瘍細胞の humam histocompatibility leukocyte antigen (以下, HLA)-class-I, 8 10 個のアミノ酸からなる peptide と T cell receptor (以下, TCR)による抗原認識が必要である.しかし, 腫瘍の HLA-class-I 分子 (以下, HLA-class-I) が消失 する症例では，この治療が無効である。この点から， 胃癌症例で HLA-class-I の陽性率を免疫組織染色より 検討した.

対象と方法：対象は胃癌ホルマリン固定標本 55 例 である. 臨床病理学的事項の記載は, 胃癌取扱い規約 第 13 版に基づいた．免疫組織学的染色は高分子ポリ マー法で, 1 次抗体は HLA class I 抗体 (Mouse monoclonal anti-human, Hokudo, Sapporo, Japan), 2 次抗体 は ChemMate envision (Rabbit polyclonal anti-mouse, Dako Cytomation, Boston, MA) であった．判定は，鏡 検で陽性染色域 $10 \%$ 未満 $(-), 10-49 \%(+), 50 \%$ 以 上 $(++)$ の 3 段階とした。陽性コントロールは，大 腸癌切除標本の正常組織, 陰性コントロールは, 反応 中で 1 次抗体を除いた。判定は病理医 1 名と臨床医 1 名で行い, 組織中に腫瘍細胞が少ないか染色么ラの例 は，除外した。

結果：判定不能は 3 例であった。これら 3 例を除く 52 例は, $(-) 8,(+) 17,(++) 27$ で $(+)$ と $(++)$ を合わせた陽性率は $84.6 \%$ であった. その組織型別陽 性比率は, pap 3/3, tub1 4/6, tub2 5/7, por1 9/10, por $216 / 18, \operatorname{sig} 1 / 1, \operatorname{muc} 3 / 3, \mathrm{AFP}$ 産生腺癌 $3 / 4$ であっ た. 深達度別陽性比率では, T1 4/8, T2 14/17, T3 21/ 22, T4 5/5 で, T1, T2 と T3, T4 で比較すると T3, T4 群に陽性率が高かった（Table 1). Stage 別では, IA 4/7, IB 3/4, II 6/7, IIIB 6/6, IV 25/28 であった.

考察 : 癌細胞と TCR の反応を構成する主な因子 は, HLA-class-I, beta-2-microglobulin, 癌抗原 peptide, HLA-class-II 分子, マクロファージや dendritic cell, $\mathrm{CD} 3 \cdot \mathrm{CD} 4 \cdot \mathrm{CD} 8$ リンパ球などがある。これらの因 子の消失により cytotoxic T lymphocyte (以下, CTL) を用いた免疫療法の効果は消失または減弱する。実際 に我々は癌 peptide-vaccine 療法で CTL 増加や peptide 特異的抗体が増加する症例に, 生存率が延長する ことを示した ${ }^{122)}$. 癌細胞の免疫機構からエスケープ現 象の一つとして HLA の消失はよく知られた現象 ${ }^{3)}$ あり，悪性黒色腫や胃，大腸，乳腺，卵巣，腎などの 癌で報告があるが，ホルマリン固定標本を用いた免疫 染色の報告はない, Heterogeneityな癌細胞の中で, HLA-class-I 陰性による免疫監視機構からの逃避は, 癌の比較的早い時期で多いことが推察された。
Table 1 The relationship between the expression of HLA-class-I antigen by immunostaining and the depth of tumor invasion

\begin{tabular}{|c|c|c|c|c|}
\hline \multicolumn{2}{|c|}{ Immunostaining } & \multirow{2}{*}{$\begin{array}{l}- \\
2\end{array}$} & \multirow{2}{*}{$\frac{+}{3}$} & \multirow{2}{*}{$\frac{++}{1}$} \\
\hline $\mathrm{T} 1$ & $\mathrm{~m}$ & & & \\
\hline \multirow{3}{*}{$\mathrm{T} 2$} & $\mathrm{sm}$ & 2 & 0 & 0 \\
\hline & $\mathrm{mp}$ & 1 & 3 & 3 \\
\hline & SS & 2 & 2 & 6 \\
\hline \multicolumn{2}{|c|}{ Subtotal } & 7 & \multicolumn{2}{|c|}{18} \\
\hline T3 & se & 1 & 7 & 14 \\
\hline $\mathrm{T} 4$ & si & 0 & 2 & 3 \\
\hline \multicolumn{2}{|c|}{ Subtotal } & 1 & \multicolumn{2}{|c|}{26} \\
\hline \multicolumn{2}{|c|}{ Total } & 8 & 17 & 27 \\
\hline
\end{tabular}

The number of positive cells in tumor tissues was determined semiquantitatively and expressed as : ( $)$, positive staining with $<10 \%$ of positive cells ; $(+)$, moderate positive staining with $<50 \% ;(++)$, strong positive staining with $50 \%$ or more. *Statistically significant at $P<0.05$ by Fisher's exact probability test

Key word : HLA-class-I

文献 : 1) Sato Y, Shomura H, Maeda Y et al : Immunological evaluation of peptide vaccination for patients with gastric cancer based on pre-existing cellular response to peptide. Cancer Sci 94 : 802-808, 2003 2) Mine T, Sato Y, Noguchi M et al : Humoral response to peptide correlate with over all survival in advanced cancer patients vaccinated with peptides based on pre-existing, peptide-specific cellular responses. Clin Cancer Res 10: 929-937, 2004 3) Kageshita T, Hirai S, Ono T et al : Down-regulation of HLA class I antigen-processing molecules in malignant melanoma. Am J Pathol 154 : 745-754, 1999

\title{
The Positive Rates of HLA-class-I Antigen in the Patients with Gastric Cancer Based on Immunohistochemical Stain- ing
}

Yuji Sato, Yosiaki Maeda, Hiroki Shomura, Shigenori Honnma, Masao Kondo, Norihiko Takahashi, Yoshie Une* and

Satoru Todo

First Department of Surgery, Hokkaido University School of Medicine

Department of Surgery, West Sapporo National Hospital*

$<2007$ 年 3 月 28 日受理 $>$ 別刷請求先 : 佐藤 裕二 $\quad$ 个166-8588

(C) 2007 The Japanese Society of Gastroenterological Surgery

杉並区阿佐谷北 $1-7-3$ 河北総合病院外科

Journal Web Site : http ://www.jsgs.or.jp/journal/ 